\title{
DETERMINANTS OF FIRM'S INNOVATION
}

\author{
Alena Zemplinerová, Eva Hromádková*
}

\begin{abstract}
:
The primary aim of the paper is an analysis of the relationships between growth, innovation and subsidies based on a large firm-level data set in the period 2004-2007. The novelty of the approach lies in linking data from financial statements with data from innovation surveys of the Czech Statistical. Innovation activities of firms are modelled as a four stage model (CDM) which allows studying several interrelated questions while controlling for simultaneity and for causality problem. In the first two stages determinants of decision to innovate and consequent innovation investment are separated. In the third stage innovation input (R\&D investment) is linked to innovation output, and finally, in the fourth stage it is determined how the productivity of firm is related to its innovation activities.
\end{abstract}

Our analysis proved that innovation input significantly increases innovation output, with increasing firm's size, however, ceteris paribus, the innovation output is decreasing. This means that bigger firms are less efficient in transforming the innovation input into output. More importantly, our analysis shows that access to subsidies has significant, yet negative influence on innovation output. This result may throw a shadow on the efficiency of supported firms and have some implications for competition policy.

Keywords: innovation, R\&D, public subsidies, competition

JEL Classification: L25, L41, 031

\section{Introduction}

Economists agree that innovation is a source of a large share of productivity growth; ${ }^{1}$ fewer consensus, however, exists as for determinants of decision firms to innovate and invest into research and development of new ideas. This paper estimates the major determinants of innovation activity among Czech companies based on a multi stage CDM micro-model. ${ }^{2}$ This model offers insight into the motives why firms pursue innovative

* $\quad$ Alena Zemplinerová, CERGE-Economics Institute, Politických vězňu 7, CZ - 111 21, Praha 1 (aln@cerge-ei.cz); Eva Hromádková, Czech National Bank, Na Prikope 28, CZ-115 03 Praha 1.

The research has been carried out with financial support of the Grant OC10062 of the Ministry of Education and P402/11/2362 of the Czech Science Foundation.

1 We use the term "innovation" in a broader sense, it refers to "scientific, technological, organizational, financial and commercial activities which lead or are intended to lead to the implementation of technologically new or improved products or services“... (OECD / Eurostat, 1997, Oslo Manual)

2 Named by authors: Crepon, Duguet and Mairesse 
strategies and allows studying several interrelated questions while controlling for simultaneity in the relationship between innovation process and firm performance and for causality problem. In the first two stages of this model, determinants of decision to innovate and consequent innovation investment are separated. In the third stage innovation input to innovation output are linked, and finally, in the fourth stage is shown how the productivity of firm is related to its innovation activities.

The major novelty of our analysis is matching the firm's data on the firm's performance recorded by Czech Statistical Office during 2003-2007 with the firm's records on innovation from surveys conducted at the firm's level by the Czech Statistical Office (CIS statistics). Merging the data on the firm's level allows us to estimate the role of subsidies which a firm receives to carry out research and development (R\&D) and relates it to the performance of firms. R\&D subsidies to firms are one of tools of technology policy, but little is known about the effects they have on the behaviour of firms, on their decision to innovate and about the efficiency of these subsidized R\&D to produce innovation and allow for the firm's growth. Our results showed that access to subsidies at national level has significant, yet negative influence on innovation output. As these same subsidies have significantly increased the $R \& D$ expenditures, this result may throw a shadow on the efficiency of supported firms and hence on the provision of subsidies to firms R\&D.

The reminder of the paper is structured as follows: Section 2 shortly reviews applied literature on innovation determinants, namely size of the firm and subsidies. Section three provides information on the data for the analysis and some descriptive statistics. Section four applies the CDM model to the Czech data and the following section presents the results. In the conclusion we address some public policy issues.

\section{Literature Overview}

Business R\&D expenditures were for a long time supposed to be crucial and direct determinant of a firm's innovation activity and its ability to absorb external knowledge which on the company level increases productivity and profit (Cohen and Levinthal, 1989). R\&D spending was expected to increase productivity by reducing the cost of production of existing goods (process innovation) or expand the choice of products (product innovation). In addition R\&D are relatively well defined and measurable variable and earlier studies considered expenditures for R\&D to be a substitute for measuring firm innovation activity (Griliches, 1986). Later, however, it has been acknowledged that $R \& D$ spending is an innovation input that cannot be used as direct measure of innovation output as not all R\&D investment leads to successful innovation. Moreover, it is not easy to measure innovation output. Innovation activity started to be analyzed as a process starting decision on R\&D investment, followed by innovation output and productivity growth.

Factors influencing innovation activity include firm age, the firm's size, and strategic features such as being a member of a group or orientation on foreign markets, barriers 
to finance innovation, level of market competition, economic situation of a country, R\&D subsidies etc. Variables that are expected to determine different components of the innovation process are so numerous that the selection (and omission) of variables is very likely to influence results of empirical studies.

First determinant of R\&D investment that we focus on is size of firm. In the economic literature in general there are two traditional theories on relationship between size of the firm and the ability to generate innovation which have different implications for the expected relationship: Schumpeterian theory (Schumpeter, 1942) claims that monopoly profit extracted from the dominant position creates enough financial resources to innovate, which in turn leads to more efficient production and better performance and thus large firms are the main source main engines to innovation. On the other hand, Arrow (1962) concludes that a firm in a competitive industry has a greater incentive to invest in research and development than a monopolist.

Similarly to the predictions of theoretical models, empirical studies do not reach unanimous conclusions regarding magnitude, significance and even sign of the relationship between size and innovation activities. The majority of empirical studies shows a positive relationship between R\&D intensity and the firm's size (e.g. Scherer, 1980). However, there are studies which have found a negative (Acs and Audretsch, 1988) or an inverted-U shaped relationship between R\&D intensity and the firm's size (Aghion et al., 2004 or Zemplinerova, 2010). A good review of empirical studies on links between market structure, the firm's size and innovation can be found in Gilbert (2006) or Cohen (2010).

One of the reasons of ambiguous results of the empirical studies on relation between the firm's size and innovation is the existence of industry-specific characteristics in the form of knowledge externalities and apropriability that can determine innovation activity (Cohen et al., 1987). The higher the opportunities arising from science, the lower are the expected costs of firm innovation (Jaffe, 1986). Appropriability is related to the possibilities and cost of imitating the innovation which differ according to industry and reach up to $50-75 \%$ of the original investment. Firms and industries vary not only as for appropriability and opportunity but also according to how able they are to network, to gather and use information, as for in-house organization of R\&D, motivation schemes, location etc. In addition, R\&D is a path-dependent process which relies on unobservable enterprise specific effects, such as the managerial style and the work culture. Firms which undertook R\&D in the pass may be more prone to use patents, trademarks or designs to prevent imitation. Recently more attention is related to institutional differences according to markets and industries (Barbosa and Faria, 2011).

The second determinant of innovation which we focus on are public subsidies to R\&D. Governments often provide significant subsidies to private R\&D to promote innovation activities of firms and thus the growth of the economy. Significant amounts

3 During last decades science provided more opportunities in biotechnology than in mechanics and textiles and accordingly we expect firms operating in these areas will engage in more R\&D. 
of public money are being spent on programmes to stimulate innovative activities. Main idea behind the firm-level R\&D subsidies is that social returns to $R \& D$ due to the positive spillover effects are higher than private returns, and thus government support to business R\&D is justified (Arrow, 1962). It is argued that because firms have problems to appropriate benefits associated with innovations, private firms invest less in R\&D innovation than would be "socially desirable" and public subsidy thus mitigates high, uninsurable risk of decisions to innovate.

Nevertheless, empirical evidence on the efficiency of subsidies to private R\&D is mixed, (see e.g. David et al. (2000) for the review of empirical studies on the relation between $R \& D$ subsidies and business $R \& D$ expenditures). While earlier studies found positive link between R\&D and subsidies (Lichtenberg, 1984), more recent studies that use modern methods of analysis and more sophisticated data report significant crowding out effect. Almus and Czarnitzki (2003) analyze the causal effects of public R\&D policy schemes on the innovation activities of firms in Eastern Germany using a non-parametric matching approach. Compared to the case in which no public financial means are provided, it turns out that firms increase their innovation activities by relatively very low percentage points close to zero. Cerulli and Poti (2008) verify a policy failure of public support on private R\&D effort by finding some cases of total crowding-out for Italian data.

As for studies investigating innovation-productivity relation, early empirical analysis of the effect of innovation on the firm's productivity and efficiency used the standard methodology - estimation using a Cobb-Douglas production function framework (for overview, see Griliches, 1995). A serious limitation of this approach is that it neglects the link labelled as "the knowledge production function" relating the R\&D inputs and outputs. This idea has been further developed by Crépon et al., (1998). Lööf and Heshmati (2002) present a simplification of the original CDM-model in which the general structure of the empirical model can be interpreted as a multi-step model consisting of four equations that tries to correct for problems with selectivity of innovation activities as well as interdependency of productivity and innovation.

The CDM model has been frequently applied by scholars using data from the Community Innovation Survey (CIS) launched by Eurostat, such as Lööf and Heshmati (2003) for Norway, Finland and Sweden, Janz et al. (2004) for Germany and Sweden, or Griffith et al. (2006) for France, Germany, Spain and the UK. One general finding is positive relationship between innovation input and output, as well as positive effect of innovation output on firm's productivity.

In the recent years similar studies have been conducted for transition countries. Masso and Vahter (2008) use CIS3 and CIS4 data combined with Estonian Business Register data to estimate the relationship for Estonia. They claim that character of innovation in the "catching-up" economy is different from developed EU countries as the innovations are much more equipment than R\&D oriented. Consistent with this assumption, they find that process innovations are a key to the productivity growth in Estonia. Variants of CDM model were also estimated for Slovenian (Damijan et al. 2005), Ukrainian 
(Vakhitova and Pavlenko, 2010) and Hungarian data (Halpern and Murakozy, 2009). Finally, Hashi and Stojcic (2010) represent first comparative study of developed and transition economies, using 16 countries participating in the CIS4 survey including all EU New Member States.

\section{Data and Descriptive Statistics}

In this paper we use two firm-level datasets gathered by the Czech Statistical Office (CZSO).

Empirical analysis is based on the Community Innovation Survey (CIS) data $2005^{4}$ and $2006^{5}$ on innovation activities undertaken by firms in the Czech Republic. We have taken the subsample of firms that were surveyed both in year 2005 and 2006 and obtained a detailed description of their innovation activities, expenditures as well as outcomes of this innovation throughout the period 2004-2006. Then, we have linked the data from CIS with the information on the firm's size (average number of employees), revenues from own products and services (in thousands CZK) and ownership (foreign/ domestic) from the CZSO longitudinal firm-level data from regular report of economic subject in producing industries (P5-01), both for the initial (2004) and final (2006) year of CIS survey. This way, we are overcoming the main problem of previous studies done on cross-section data, namely simultaneity between R\&D investment and productivity, because we analyze how the R\&D investment in some period affects productivity of firm two periods after.

CZSO also provided us with the information from the Registry of Economic Subjects, containing the data on the date of enlistment of economic subject into the registry (firm enters the market), as well as possible termination of activities (firm exists the market). This is important mainly from the point of view of market dynamics and market competition. It should enable us to determine the importance of competition via innovation within incumbent firms as compared to newly entering firms.

Final sample consists of 2071 firms and summary statistics of selected variables can be found in Tables 1a and 1b. In Table 1a we compare the characteristics of firms that innovated (approx. 52\% of the sample) and firms that did not innovate throughout the period 2004-2006. There is distinctive pattern of differences between two types of firms: Innovating firms are significantly bigger in terms of employment, they are more productive on average both before and after introduction of innovation, they have higher probability to have foreign ownership. Innovation is also much more widespread among firms which are oriented on foreign markets (EU and other countries) and are incumbents. We also see that most of innovation activities take place in manufacturing industries.

4 For the full summary of the findings of CIS 2006 (covering years 2004-2006) in the Czech Republic, please see http://www.czso.cz/csu/2006edicniplan.nsf/publ/9605-06-v_roce_2005.

5 For the full summary of the findings of CIS 2005 (covering years 2003-2005) in the Czech Republic, please see http://www.czso.cz/csu/2006edicniplan.nsf/publ/9605-06-v_roce_2005. 
Table 1a

Summary Characteristics of the Sample: Comparison of Innovating and Non-Innovating Firms

\begin{tabular}{|l|c|c|c|c|}
\hline & \multicolumn{2}{|c|}{$\begin{array}{c}\text { Innovating } \\
\text { firms }\end{array}$} & \multicolumn{2}{c|}{$\begin{array}{c}\text { Non-innovating } \\
\text { firms }\end{array}$} \\
\hline Number of firms (\% of total) & 1069 & $52 \%$ & 1002 & $48 \%$ \\
\hline Firm's size & Mean & SE & Mean & SE \\
\hline Labour productivity (2004) & $616^{* * *}$ & {$[73]$} & $259^{* * *}$ & {$[14]$} \\
\hline Labour productivity (2006) & $2234^{* * *}$ & {$[74]$} & $1915^{* * *}$ & {$[76]$} \\
\hline Part of group & $2639^{* * *}$ & {$[92]$} & $2191^{* * *}$ & {$[86]$} \\
\hline Foreign ownership & $0.56^{* * *}$ & {$[0.081]$} & $0.37^{* *}$ & {$[0.145]$} \\
\hline New entrant & $0.35^{* *}$ & {$[0.015]$} & $0.31^{* *}$ & {$[0.015]$} \\
\hline Market orientation & $0.03^{* * *}$ & {$[0.005]$} & $0.06^{* * *}$ & {$[0.007]$} \\
\hline - regional & \multicolumn{5}{|l|}{} & {$[0.014]$} \\
\hline - national & $0.11^{* * *}$ & {$[0.010]$} & $0.27^{* * *}$ & {$[0.015]$} \\
\hline - EU & 0.38 & {$[0.015]$} & 0.4 & {$[0.4$} \\
\hline - other countries & $0.41^{* * *}$ & {$[0.015]$} & $0.29^{* * *}$ & {$[0.014]$} \\
\hline Industry & $0.10^{* * *}$ & {$[0.009]$} & $0.04^{* * *}$ & {$[0.006]$} \\
\hline Manufacturing & \multicolumn{5}{|l}{} & {$[0.016]$} \\
\hline Services & $0.68^{* * *}$ & {$[0.014]$} & $0.46^{* * *}$ & {$[0.014]$} \\
\hline Trade & $0.19^{* * *}$ & {$[0.012]$} & $0.28^{* * *}$ & {$[0.009]$} \\
\hline
\end{tabular}

Standard errors in parenthesis. *,** and ${ }^{* * *}$ denote statistical difference between the mean values of innovating and non-innovating firms at $10 \%, 5 \%$ and $1 \%$ level.

In Table $1 \mathrm{~b}$ we report summary statistics for innovating firms only, namely average expenditures on innovation, types of innovation they introduce as well as access to subsidies, either at national or EU level. From Table $1 \mathrm{~b}$ which is related only to innovating firms follows that expenditures on $R \& D$ are growing over time. Beside above described product and process innovation, we are able to distinguish another two types of innovation - organizational innovation when firm introduced new or improved knowledge management system, changed management structure, integrated different activities or introduced changes in its relations with other enterprises or public institutions during 2004-06 and marketing innovation firm when introduced significant changes to packaging of goods or services, or changed its sales or distribution methods during 2004-06. Marketing innovation is least frequent type of innovation. 
Table $1 b$

Summary Characteristics of the Sub-Sample: of Innovating Firms

\begin{tabular}{|l|c|c|}
\hline \multicolumn{3}{|l|}{ Average expenditures on R\&D (in thousands CZK) } \\
\hline Total & 122,081 & {$[574,834]$} \\
\hline - in 2004 & 34,687 & {$[162,305]$} \\
\hline - in 2005 & 40,356 & {$[220,240]$} \\
\hline - in 2006 & 47,038 & {$[248,490]$} \\
\hline Types of innovation (\% of firms) & \multicolumn{2}{|c|}{} \\
\hline - product & 76.8 & {$[42.2]$} \\
\hline - process & 82.4 & {$[38.1]$} \\
\hline - marketing & 40.9 & {$[49.2]$} \\
\hline - organizational & 73.9 & {$[43.9]$} \\
\hline Access to subsidies (\& of firms) & 2.9 & {$[17.1]$} \\
\hline - regional & 22.8 & {$[41.9]$} \\
\hline - national & 9.6 & {$[29.5]$} \\
\hline - EU & \multicolumn{2}{|c|}{1069} \\
\hline Number
\end{tabular}

Standard errors in parenthesis

\section{Model Specification}

As mentioned above, inspired by CDM model (Crepon et. al, 1998), as well as its application by Hashi and Stojcic (2010), we model the innovation activities of Czech firms as a four stage model. The CDM model allows studying several interrelated questions while controlling for simultaneity in the relationship between innovation and performance (endogeneity) and causality problem. At the first step of the model, firms decide whether or not to engage in innovation activities (selection equation), and conditional on this decision they choose how much they will invest in R\&D. In the first two stages we separate determinants of decision to innovate and consequent innovation investment.

In the third stage we link innovation input ( $R \& D$ investment) to innovation output, and finally, in the fourth stage we determine how the productivity of firm is related to its innovation activities using instrumental variables approach. In two last steps there exists a problem of simultaneity: innovation output is expected to boost performance of the firm. At the same time however higher efficiency (profitability, productivity) allows to improve the output of innovation. From this reason it was necessary to find an "instrument" which does directly affect output of innovations but does not have direct impact on the firm's performance. In our case we used "barriers to innovation" which was one of the survey questions. 


\subsection{Decision to innovate and innovation input:}

$\mathrm{CDM}$ assumes that there exists a latent (unobserved) dependent variable $\mathrm{g}_{\mathrm{i}}^{*}$ that expresses the investment decision criterion (e.g. expected net present value of profit accruing to research investment). Firms with $\mathrm{g}_{\mathrm{i}}{ }^{*}$ above some level choose to invest in research. This can be expressed as

$$
\begin{aligned}
g_{i}^{*} & =\beta_{0} x_{i}^{0}+u_{i}^{0} \\
g_{i} & =1 \quad \text { if } \quad g_{i}^{*}>0 \\
& =0 \quad \text { if } \quad g_{i}^{*} \leq 0
\end{aligned}
$$

where $\mathrm{x}_{\mathrm{i}}^{0}$ is the vector of variables that determine the decision to innovate and invest into R\&D. R\&D expenditures suffer from shortcomings which limit their applicability as a direct measure of innovation. Our variable "R\&D expenditures" includes all costs (own research employees/human capital and facilities, external R\&D, knowledge embodied in the new machinery and software). We assume that only a part of inputs (R\&D expenditures) leads to innovation output.

The innovation investment (captured by innovation expenditures) conditional on decision to innovate is then denoted by $\mathrm{k}_{\mathrm{i}}$ and can be expressed as

$$
\begin{aligned}
& k_{i}^{*} \mid\left(g_{i}^{*}>0\right)=\beta_{1} x_{i}^{1}+u_{i}^{1} \\
& k_{i}=k_{i}^{*} \text { if } k_{i}^{*}>0 \\
& =0 \text { otherwise }
\end{aligned}
$$

where $\mathrm{x}_{\mathrm{i}}{ }^{1}$ is the vector of variables that determine the level of innovation expenditures. In the implementation of the model, we assume that a firm has taken decision to innovate (i.e. $\mathrm{g}_{\mathrm{i}}=1$ ) if through years 2004-2006 it has undertaken any of the following activities: (1) introduced new or substantially improved product or service; (2) introduced new or substantially improved production method or improvement in logistics, supplies or distribution of its products or services, introduced new supporting activities (maintenance, accounting, IT, etc.); (3) had any on-going/abandoned innovation activities. This decision to innovate is then modelled as function of: the firm's size as of $2004^{6}$ (natural logarithm of employment); three dummy variables for market orientation (national, EU, other); ${ }^{7}$ dummy variable for being part of group of firms; dummy variable for foreign ownership (based on the reported institutional sector); dummy variable for being new entrant; four dummy variables for reporting factors hampering innovation (economical - financial, knowledge, market, other); ${ }^{8}$ two dummy variables for existing organizational and marketing innovations.

6 We have chosen to use the employment level from the year 2004 - i.e. the year when the decision was taken. This way we can avoid the problem of reverse causation, i.e. the effect of innovation activities on the growth of the firm's size.

7 Baseline category being operation on regional market.

8 These factors are included to account for the external determinants of innovation decision. 
Innovation investment is measured by logarithm of sum of total innovation expenditures over period 2004-2006. In comparison to equation describing decision to innovate, to explain the intensity of investing we use following additional explanatory variables: three dummy variables for use of different sources of subsidies (regional, national or EU sources) and four dummy variables for highly important sources of information on innovation activities (coming from internal sources, market, institutions or other sources). Also, we exclude dummies for market and other factors hampering innovation, as we believe that they primarily influence decision to innovate rather than the actual amount of innovation investment. In both equations, we control for the industry (manufacture, services, trade). ${ }^{9}$ We estimate both equations jointly by the generalized tobit routine in STATA, using all firms in the sample, both those who innovate and those who do not.

\subsection{Innovation output and its effect on the productivity of firm}

We estimate the innovation production equation where we link innovation output $s_{i}$ with the innovation input $\mathrm{k}_{\mathrm{i}}$

$$
s_{i}=\alpha_{k} k_{i}+\beta_{2} x_{i}^{2}+u_{i}^{2}
$$

We introduce innovation output $\mathbf{s}_{\mathrm{i}}$ as logarithm of the share of sales of new products and services in the total revenue of the firm in year 2006. ${ }^{10}$ Explanatory variables of production of innovations are: innovation input (sum of innovation expenditures over period 2004-2006); inverse Mills ratio from the innovation decision equation (to account for possible selection bias); the firm's size as of 2006; logarithm of labour productivity in 2006; dummy indicating that firm will be involved in fusion in future; three dummy variables for receiving of subsidies (from regional, government and EU resources); dummy variable for innovation cooperation with suppliers/customers/research institutions; three dummy variables indicating whether innovations are by firm perceived as highly important for their products, processes or other business activities. ${ }^{11}$

Finally, we measure performance of the firm in terms of labour productivity, computed as total revenues from own products and services over the employment in 2006. Productivity equation is defined as

$$
q_{i}=\alpha_{s} s_{i}+\beta_{3} x_{i}^{3}+u_{i}^{3}
$$

9 Baseline category being other industry

10 Alternative measure is number of patents (feasible within the data) That, however, is not a good measure of innovation output as only a few patents are associated with valuable inventions and most patents describe inventions of little value. Patents are also industry specific (often used in pharmaceuticals but very little in other sectors).

11 In the initial regression, we have also introduced dummies for marketing and organization innovation, as well as dummies for the highly important sources of information. These, however, did not pass joint significance tests. 
where determinants of the productivity are: innovation output $\mathrm{s}_{\mathrm{i}}$; firm size as of 2006; dummy variable for foreign ownership; dummy variable indicating that firm will be involved in merger in future; measure of concentration in the industry (HerfindahlHirschman Index index at 3-digit OKEC level); existing organizational and marketing innovations; factors hampering innovation (to account for limitations of transfer of innovation to productivity) and dummy variable for being part of group of firms. Again, both models include dummy variables for manufacturing, service and trade industries.

These two equations are estimated as system on the sample of firms that have reported positive amount of innovation output. We are using three-stage least squares estimation of simultaneous equations which allows for the feedback from the labour productivity to innovation output.

\section{Results}

\subsection{Decision to innovate and innovation input}

Table 2 summarizes results from the estimation of determinants of the innovation decision of firm, as well as consecutive decision on the amount of finances invested to produce innovation. It follows from the results that probability that a firm decides to innovate is increasing in its size. Bigger firms also invest higher amounts of money to develop innovation. These results can be explained by advantages of large firms as compared to small firms in financing $\mathrm{R} \& \mathrm{D}$, possibility to diversify risks which is very high in case in innovation as well as scale economies in R\&D.

Our results show that firms that are oriented on foreign markets are more innovative and also make greater innovation investments. Orientation on foreign markets - as we expected - facilitate decision of firms to innovate in order to remain competitive. Competition on foreign (larger) market is more intensive than on domestic or local market and competition via innovation is more important.

According to our results foreign ownership decreases probability of innovation decision, probably due to direct transfer of knowledge and technology from the mother firm as R\&D in multinational companies is as a rule centralized in headquarters (Cantwell and Zayas, 2003). This result is in line with analysis of Srholec (2005) who using data from the third Community Innovation Survey (CIS) found that foreign affiliates tend to engage less in internal R\&D compared with domestic owned firms. Also, Zemplinerova (2010) showed that there exists negative relation between foreign ownership of the firm and numbers of R\&D employees - in comparison to domestic firms, foreign firms have less R\&D employees. ${ }^{12}$ Our model also indicates that being a part of the group increases probability of innovation, probably due to the fact that these firms can also invest more, as they are backed up by group finances.

12 Number of employees is an important indicator as about half of $R \& D$ expenditures are created by wages of engineers and scientists who create a knowledge base of a company. 
Table 2

Determinants of Innovation Decision and Innovation Investment of Firms in the Czech Republic (2004-2006), Generalized Tobit Estimation

\begin{tabular}{|c|c|c|c|c|c|}
\hline & \multicolumn{2}{|c|}{$\begin{array}{l}\text { Innovation } \\
\text { decision }\end{array}$} & \multirow[b]{2}{*}{ marg.effect } & \multicolumn{2}{|c|}{$\begin{array}{l}\text { Innovation } \\
\text { Investment }\end{array}$} \\
\hline & coef & SE & & coef & SE \\
\hline Firm's size (In) & $0.120^{* * *}$ & [0.028] & 0.048 & $0.672^{* * *}$ & [0.053] \\
\hline \multicolumn{6}{|l|}{ Market orientation } \\
\hline - national & $0.173^{*}$ & [0.099] & 0.069 & 0.161 & [0.210] \\
\hline - EU & $0.307^{* * *}$ & {$[0.114]$} & 0.121 & $0.442^{*}$ & [0.231] \\
\hline - other countries & $0.342^{\star *}$ & [0.163] & 0.133 & $0.609^{* *}$ & [0.281] \\
\hline Part of group & $0.299^{* * *}$ & [0.081] & 0.118 & $0.331^{* *}$ & [0.145] \\
\hline Foreign ownership & $-0.194^{* *}$ & {$[0.086]$} & -0.077 & $0.273^{*}$ & [0.146] \\
\hline New entrant & $-0.367^{* *}$ & {$[0.171]$} & -0.145 & 0.027 & [0.334] \\
\hline \multicolumn{6}{|c|}{ Factors hampering innovation } \\
\hline - cost (financing) & 0.128 & {$[0.083]$} & 0.051 & $-0.372^{* * *}$ & [0.131] \\
\hline - knowledge & 0.201 & {$[0.108]$} & 0.065 & -0.056 & [0.155] \\
\hline - market & $0.201^{* *}$ & {$[0.091]$} & 0.079 & - & - \\
\hline - other reasons & $-1.11^{\star \star \star}$ & {$[0.107]$} & -0.402 & - & - \\
\hline Organization innovation & $0.963^{* * *}$ & {$[0.069]$} & 0.369 & -0.071 & [0.230] \\
\hline Marketing innovation & $0.732^{* * *}$ & {$[0.088]$} & 0.278 & -0.036 & [0.159] \\
\hline \multicolumn{6}{|l|}{ Access to subsidies } \\
\hline - regional & - & - & - & 0.285 & [0.334] \\
\hline - national & - & - & - & $0.750^{* * *}$ & [0.151] \\
\hline - EU & - & - & - & $0.339^{*}$ & {$[0.250]$} \\
\hline \multicolumn{6}{|l|}{ Sources of information } \\
\hline - internal & - & - & - & $0.284^{*}$ & [0.172] \\
\hline - market & - & - & - & $0.782^{* \star *}$ & [0.230] \\
\hline - institutional & - & - & - & $0.283^{\star *}$ & [0.136] \\
\hline - other & - & - & - & $0.255^{*}$ & [0.135] \\
\hline \multicolumn{6}{|l|}{ Industry } \\
\hline Manufacturing & $0.469^{* * *}$ & {$[0.116]$} & 0.185 & -0.086 & [0.252] \\
\hline Services & 0.037 & {$[0.160]$} & 0.014 & -0.542 & [0.341] \\
\hline Trade & $0.231^{*}$ & {$[0.118]$} & 0.092 & -0.131 & [0.254] \\
\hline Number & 2071 & & & 3912 & \\
\hline pseudo R2 & 0.332 & & & - & \\
\hline
\end{tabular}

Standard errors in parenthesis. * ${ }^{* *}$ and ${ }^{* *}$ denote statistical inference at $10 \%, 5 \%$ and $1 \%$ level. 
We find that, consistent with intuition, economic factors such as high cost of financing innovations are negatively correlated with innovation investment. As mentioned above, financing of technological $R \& D$ is problematic because of low expected returns due to an inability to appropriate the profits from an invention and the uncertainty and risk associated with the project. This may be also explanation why new entrants are less involved in innovation activities as well as the fact that use of any sources of information is positively and significantly correlated with higher innovation expenditures because information decrease the level of uncertainty. In terms of the amount invested, our results show that access to subsidies (either on governmental or EU level) increases the innovation expenditures of firms. ${ }^{13}$ This finding is in line with Almus and Czarnitzki (2003) who found similar result using dataset of firms in Eastern Germany, or more recently Gonzales, Jaumandreu and Pazo (2005) on firm-level Spanish data.

\subsection{Innovation output and productivity}

Table 3 summarizes determinants of innovation output of firms in the Czech Republic. As expected the innovation output has significant and positive effect on the productivity of the firms. Our results show that innovation input significantly increases innovation output, where the transformation ratio is approximately $0.15 \%$ more of innovation output from additional $1 \%$ of innovation input.

With increasing the firm's size, however, keeping all other constant, the innovation output is decreasing. This means that bigger firms are less efficient in transforming the innovation input into output. Our result is in line with conclusions of Cohen and Klepper (1996) that summarize the findings about the relationship between innovation and the firm's size, most important being that the probability of innovation activities increases in firm's size, while the innovation output at given level of innovation investment is decreasing in firm's size.

Access to subsidies at national level has significant, yet negative influence on innovation output. As these same subsidies have significantly increased the innovation activity and expenditures in the first step, this result may throw a shadow on the efficiency of supported firms. Similarly to us, Hashi and Stojcic (2010) found that firms receiving national or EU subsidies spend more on innovation investment but produce less innovation output than firms which do not receive subsidies. 
Table 3

Determinants of Innovation Output of Firms in the Czech Republic (2006), Three Stage Least Squares Estimation of System of Equations

\begin{tabular}{|l|c|c|}
\hline \multirow{2}{*}{} & \multicolumn{2}{|c|}{ Innovation output } \\
\cline { 2 - 3 } & Coef. & SE \\
\hline Innovation input (log) & $0.146^{* * *}$ & {$[0.027]$} \\
\hline Inverse Mill's ratio & -0.194 & {$[0.129]$} \\
\hline Firm size (log) & $-0.175^{\star * *}$ & {$[0.041]$} \\
\hline Labour productivity (log) & 0.045 & {$[0.132]$} \\
\hline Merger (in future) & $-0.357^{* *}$ & {$[0.183]$} \\
\hline Innovation cooperation & $0.115^{*}$ & {$[0.066]$} \\
\hline Access to subsidies & \multicolumn{2}{|c|}{} \\
\hline - regional & -0.041 & {$[0.179]$} \\
\hline - national & $-0.158^{* *}$ & {$[0.077]$} \\
\hline - EU & 0.013 & {$[0.102]$} \\
\hline Importance of innovation & \multicolumn{2}{|c|}{} \\
\hline - effect on product & $0.231^{* * *}$ & {$[0.078]$} \\
\hline - effect on processes & 0.051 & {$[0.064]$} \\
\hline - other effect & $0.171^{* *}$ & {$[0.075]$} \\
\hline Industry & $0.557^{* * *}$ & {$[0.203]$} \\
\hline Manufacturing & $0.443^{* *}$ & {$[0.224]$} \\
\hline Services & 0.139 & {$[0.316]$} \\
\hline Trade & \multicolumn{2}{|c|}{} \\
\hline Number & \multicolumn{2}{|c|}{} \\
\hline
\end{tabular}

In the Table 4 which summarizes determinants of labour productivity of firms we see that labour productivity is increasing with the group membership, foreign ownership and concentration of the industry. Also, firms that will be involved in merger in future are more productive today. Foreign owned firms that make most of their business on international markets tend to invest more into their innovation-related processes but as mentioned above they tend to locate $R \& D$ departments in headquarters. This, however, allows them to compete with higher productivity with domestic firms. 
Table 4

Determinants of Labour Productivity of Firms in the Czech Republic (2006), Three Stages Least Squares Estimation of System of Equations

\begin{tabular}{|c|c|c|}
\hline & \multicolumn{2}{|c|}{ Productivity } \\
\hline & coef & SE \\
\hline Innovation output & $0.531^{* * *}$ & [0.121] \\
\hline Firm size & 0.039 & [0.032] \\
\hline Part of group & $0.387^{* * *}$ & [0.070] \\
\hline Foreign investor & $0.289^{* * *}$ & [0.067] \\
\hline Merger (in future) & $0.414^{* * *}$ & [0.161] \\
\hline Concentration (HHI) & $0.582^{\star * *}$ & [0.184] \\
\hline \multicolumn{3}{|c|}{ Factors hampering innovation } \\
\hline$-\cos t$ & -0.063 & [0.064] \\
\hline - knowledge & $-0.157^{\star *}$ & [0.068] \\
\hline - market & $-0.133^{* *}$ & [0.067] \\
\hline - other reasons & 0.266 & [0.179] \\
\hline Organization innovation & -0.027 & [0.064] \\
\hline Marketing innovation & -0.037 & [0.053] \\
\hline \multicolumn{3}{|l|}{ Industry } \\
\hline Manufacturing & $-0.828^{* * *}$ & [0.142] \\
\hline Services & $-0.979^{* * *}$ & [0.191] \\
\hline Trade & 0.432 & [0.273] \\
\hline Number & \multicolumn{2}{|c|}{803} \\
\hline
\end{tabular}

Numerous studies analyze effects of the activities of multinational firms on the host economy. When a firm invests in a foreign country, it often brings with it technological know-how, however, the spillover effects are not unanimous. On the one hand, the entry of higher productivity company can encourage other companies within the same industry to improve their performance. That can happen due to the imitating new technologies or by hiring trained workers and managers from foreign-owned companies. On the other hand, those domestic companies that are not able to catch up with the higher performance of other companies within the industry may be forced to exit the market (crowded out of the market). As a result there is no clear evidence of aggregate positive horizontal spillovers of FDI (Javorcik, 2004). There exists some evidence that technology spillovers from horizontal FDI can be proved in high-tech sectors but not in low-tech sectors (Keller and Yeaple, 2009).

We also find that knowledge and market factors hampering innovation are statistically significant and negative. There is no significant effect of existence of marketing or 
organization innovation on productivity of firm found. Probably the full effect of innovation activities is captured in the innovation output measured by additional sales. Interestingly, firms in manufacturing and services have lower productivity as opposed to firms operating in the trade and other industries.

\section{Conclusion}

In our article we focused on public subsidies to private $R \& D$ as one of the determinants of firm innovation activity. Large amounts of public money are spent to stimulate private innovative activities and these amounts are supposed to grow in the future. We found that although subsidies have significantly increased the innovation inputs, access to subsidies at national level has significant, yet negative influence on innovation output. We have also found that the probability that firm decides to innovate is increasing in its size and bigger firms invest higher amounts of money to develop innovation. At the same time, however, with increasing firm size ceteris paribus, the innovation output is decreasing. This means that bigger firms are less efficient in transforming the innovation input into output. Our results are broadly consistent with previous empirical literature which also raises doubts with respect to efficiency of the public subsidies to private $R \& D$ in general and to large firms in particular.

Analysis of the effects of R\&D subsidies as well as effects of the size of the firm on the production of innovation and the firm's productivity has important implications for competition policy. In practice, competition authorities are very strict as for cartel agreements between firms. In case of large research consortia or large mergers that claim the necessity of R\&D concentration, however, the enforcement of competition policy is rather soft. As for subsidies to enterprises, they are in general prohibited by EU Treaty because they harm competition and free trade. EU and national governments of member states however continue to provide R\&D subsidies to firms in order to boost innovation in the business and the competition authorities are ready to provide exemptions from the law.

At present competition authorities tend to tolerate $R \& D$ cooperation within certain bounds and approve state aid to firm R\&D because it is assumed that this raises welfare. Reasons for approvals of $R \& D$ concentrations and cooperation is expectation of economies of scale in $R \& D$, a large minimum efficient scale in $R \& D$ required to produce major innovations or efforts to eliminate parallel research - reasons which cannot be unanimously confirmed by economic literature. The risk that R\&D cooperation may start the collusion in the product market is high. Subsidies to R\&D imply re-distribution of resources and distort price signals. In addition a subsidy can alter behaviour of firms. A recipient may be cushioned and suffer by soft budget constraints. In addition large companies have better chances to succeed in getting subsidies due to their political power. 


\section{References}

Acs, Z. J., Audretsch, D. B. (1988), "Innovation in Large and Small Firms: An Empirical Analysis." The American Economic Review, 78(4), pp. 678-690.

Aghion, P., Bloom, N., Blundell, R. W., Griffith, R., Howitt, P. (2004), "Competition and Innovation: An Inverted U Relationship." SSRN eLibrary. Retrieved from http://papers.ssrn.com/sol3/papers. cfm?abstract_id $=1306944$

Almus, M., Czarnitzki, D. (2003), "The Effects of Public R\&D Subsidies on Firms' Innovation Activities: The Case of Eastern Germany.” Journal of Business \& Economic Statistics, 21(2), pp. 226-236.

Arrow, K. (1962), "Economic Welfare and the Allocation of Resources for Invention." In Nelson, R. R. ed. The Rate and Direction of Inventive Activity: Economic and Social Factors (pp. 609-626). Princeton: Princeton University Press.

Barbosa, N., Faria, A. P. (2011), "Innovation across Europe: How Important are Institutional Differences?" Research Policy, In Press, Corrected Proof. doi:16/j.respol.2011.05.017

Cantwell, J., Zayas, J. M. (2003), Multinational enterprises, innovative strategies and systems of innovation. Edward Elgar Publishing.

Cerulli, G., Poti, B. (2008), "Evaluating the Effect of Public Subsidies on Firm R\&D Activity: an Application to Italy Using the Community Innovation Survey." (Working Paper No. 9). CERIS-CNR Anno 10. Moncalieri (TO): Institute for Economic Research on Firms and Growth. Retrieved from http://ideas.repec.org/p/csc/cerisp/200809.html

Cohen, W. M. (2010), "Fifty Years of Empirical Studies of Innovative Activity and Performance." Handbook of the Economics of Innovation, Vol. 1 (Vol. 1, pp. 129-213). North-Holland. Retrieved from http://www.sciencedirect.com/science/article/pii/S016972181001004X.

Cohen, W. M., Klepper, S. (1996), "A Reprise of Size and R \& D." The Economic Journal, 106(437), 925-951. doi:10.2307/2235365.

Cohen, W. M., Levinthal, D. A. (1989), "Innovation and Learning: The Two Faces of R \& D." The Economic Journal, 99(397), pp. 569-596. doi:10.2307/2233763.

Cohen, W. M., Levin, R. C., Mowery, D. C. (1987), "Firm Size and R \& D Intensity: A Re-Examination." The Journal of Industrial Economics, 35(4), pp. 543-565.

Crepon, B., Duguet, E., Mairesse, J. (1998), "Research, Innovation and Productivity: An Econometric Analysis at the Firm Level." Economics of Innovation and New Technology, 7(2), pp. 115-158. doi:http://www.tandf.co.uk/journals/titles/10438599.asp

Damijan, J. P., Jaklic, A., Rojec, M. (2005), "R\&D Spillovers, Innovation and Firms' Productivity Growth in Slovenia." (Working Paper). Understanding the Relationship between Knowledge and Competitiveness in the Enlarging European Union (U-Know). Leuven: Sixth Framework Programme project. Retrieved from http://www.etsg.org/ETSG2007/papers/kostevc.pdf.

David, P. A., Hall, B. H., Toole, A. A. (2000), "Is Public R\&D a Complement or Substitute for Private R\&D? A Review of the Econometric Evidence." Research Policy, 29(4-5), pp. 497-529. doi:16/ S0048-7333(99)00087-6.

Gilbert, R. J. (2006), "Looking for Mr. Schumpeter: Where Are We in the Competition--Innovation Debate?" Innovation Policy and the Economy, 6, pp.159-215.

González, X., Jaumandreu, J., Pazó, C. (2005), "Barriers to Innovation and Subsidy Effectiveness." The RAND Journal of Economics, 36(4), pp. 930-950.

Griffith, R., Huergo, E., Mairesse, J., Peters, B. (2006), "Innovation and Productivity Across Four European Countries." Oxford Review of Economic Policy, 22(4), pp. 483-498. doi:10.1093/ oxrep/grj028.

Griliches, Z. (1986), "Productivity, R and D, and Basic Research at the Firm Level in the 1970's." The American Economic Review, 76(1), pp. 141-154. 
Griliches, Z. (1995), "R\&D and Productivity: Econometric Results and Measurement Issues." Handbook of the Economics of Innovation and Technological Change (pp. 52-89). Oxford: Blackwell Publishers.

Halpern, L., Murakozy, B. (2009), "Innovation, Productivity and Exports: the Case of Hungary." (Working Paper No. MT-DP - 2009/21). IEHAS Discussion Papers. Institute of Economics, Hungarian Academy of Sciences. Retrieved from http://ideas.repec.org/p/has/discpr/0921.html.

Hashi, I., Stojcic, N. (2010), "The Impact of Innovation Activities on Firm Performance Using a Multi-Stage Model: Evidence from the Community Innovation Survey 4." (Working Paper No. 410/2010). Network Studies and Analyses. Warsaw: CASE. Retrieved from http://papers. ssrn.com/sol3/papers.cfm?abstract_id=1680935.

Jaffe, A. B. (1986), "Technological Opportunity and Spillovers of R\&D: Evidence from Firms' Patents, Profits and Market Value." American Economic Review, 76(5), pp. 984-1001. doi:10.1111/1468-2370.00024.

Janz, N., Lööf, H., Peters, B. (2004), "Firm Level Innovation and Productivity - Is There a Common Story Across Countries?" Problems and Perspectives in Management, Vol. 2, pp. 184-204.

Javorcik, B. S. (2004), "Does Foreign Direct Investment Increase the Productivity of Domestic Firms? In Search of Spillovers Through Backward Linkages." The American Economic Review, 94(3), pp. 605-627. doi:10.1257/0002828041464605.

Keller, W., Yeaple, S. R. (2009), "Multinational Enterprises, International Trade, and Productivity Growth: Firm-Level Evidence from the United States." Review of Economics and Statistics, 91(4), pp. 821-831. doi:i: 10.1162/rest.91.4.821</p>.

Lichtenberg, F. R. (1984), "The Relationship between Federal Contract R\&D and Company R\&D." The American Economic Review, 74(2), pp. 73-78.

Lööf, H., Heshmati, A. (2002), "Knowledge Capital and Performance Heterogeneity: A Firm-Level Innovation Study." International Journal of Production Economics, 76(1), pp. 61-85. doi:16/ S0925-5273(01)00147-5.

Lööf, H., Heshmati, A. (2003), "The Link between Firm-Level Innovation and Aggregate Productivity Growth: a Cross-Country Examination.” Research Evaluation, 12(2), pp. 131-147. doi:10.3152/147154403781776654.

Masso, J., Vahter, P. (2008), "Technological Innovation and Productivity in Late-Transition Estonia: Econometric Evidence from Innovation Surveys." The European Journal of Development Research, 20(2), pp. 240-261. doi:10.1080/09578810802060751.

Scherer, F. M. (1980), Industrial Market Structure and Economic Performance (2nd ed.). Chicago: Rand McNally College Pub. Co.

Schumpeter, J. (1942), Capitalism, Socialism and Democracy. Harper and Row.

Srholec, M. (2005), "Innovation Strategies of Multinationals: Firm-Level Evidence from Foreign Affiliates in the Czech Republic." (Working Paper). Proceedings from the 31th EIBA Annual Conference. Oslo: EIBA - European International Business Academy. Retrieved from http://folk. uio.no/martinsr/pdf/0512_EIBA_Srholec_CDrom.pdf.

Vakhitova, G., Pavlenko, T. (2010), "Innovation and Productivity: a Firm Level Study of Ukrainian Manufacturing Sector." (Working Paper No. 27). Discussion Papers. Kyiv: School of Economics. Retrieved from http://ideas.repec.org/p/kse/dpaper/27.html.

Zemplinerová, A. (2010), "Innovation Activity of Firms and Competition." Politická ekonomie, 2010, Vol. 58, No. 6, pp. 747-760. 